\title{
THE PERILS OF JARGONS: HOW ILLUSION OF KNOWLEDGE OBSCURES TRUE TEACHER COMPETENCE
}

\author{
Henry Wijaya \\ Guangdong University of Foreign Studies, Tiongkok \\ email: henrywijaya@outlook.com
}

\begin{abstract}
Teacher competence is a crucial factor to the success of BIPA teaching and learning. In terms of pedagogy, a competent BIPA teacher naturally is not only proficient at theories, but also adept at materializing them into classroom instructions, to help students learn effectively. Nonetheless, trapped inside knowledge illusion of one's own competence, a teacher might believe to have grasped the latest development in language teaching, while in fact, although capable of reciting jargons smoothly, that teacher still teaches traditionally. This article (re-)visits trends in modern language teaching, reflecting on which one has genuinely understood and fully implemented, and which still require our study. Ultimately, this article expects to contribute to the larger discussion of how BIPA teacher competence should be defined and could be improved.
\end{abstract}

Keywords: teacher competence, language pedagogy, classroom practice, jargons, reflection

\section{MARA BAHAYA JARGON: BAGAIMANA ILUSI PENGETAHUAN MENGABURKAN KOMPETENSI PENGAJAR YANG SESUNGGUHNYA}

\begin{abstract}
Abstrak
Kompetensi pengajar merupakan faktor utama keberhasilan proses pembelajaran BIPA. Dalam hal pedagogi, pengajar yang berkompeten sewajarnya tidak hanya mahir dalam teori pengajaran, tetapi juga terampil mewujudkannya ke dalam praktik kelas guna membantu pemelajar belajar dengan efektif. Namun, ketika terjebak dalam ilusi pengetahuan tentang kompetensi, bisa jadi kita percaya telah seutuhnya memahami perkembangan terkini dalam bidang pengajaran bahasa, padahal, meski mampu melafalkan berbagai jargon secara fasih, nyatanya kita masih saja mengajar secara tradisional. Tulisan ini menyelisik (kembali) pelbagai tren pengajaran bahasa modern untuk merenungkan mana yang telah sungguh-sungguh kita pahami dan sepenuhnya terapkan, dan yang masih perlu kita pelajari lebih lanjut. Penulisan ini juga diharapkan berkontribusi terhadap diskusi yang lebih luas mengenai pemerian kompetensi pengajar BIPA dan upaya peningkatannya.
\end{abstract}

Kata Kunci: kompetensi pengajar, pedagogi bahasa, praktik pengajaran, jargon, refleksi 


\section{INTRODUCTION}

The teaching of Indonesian language to foreign learners (Bahasa Indonesia bagi Penutur Asing or BIPA, hereafter) is arguably an essential part of the efforts to promote our national language, whereas the competence of its teacher is arguably a crucial - if not the most significant-factor to the success of BIPA teaching and learning process.

In the globalization era, which poses complex challenges, teachers are demanded to continuously develop their competence in order to keep up with the constant changes of their students' needs (Altun, 2011; Nessipbayeva, 2012).

As Muliastuti (2017) has explained, teaching staff development is one of BIPA development tasks prescribed in the National Language Policy (Politik Bahasa Nasional). She added that the rising number of the teachers should go hand in hand with teaching quality improvement, which could be attained through several steps, such as teacher education and certification. It is thus obvious that becoming competent is a common goal that every BIPA teacher should pursue.

In relation to competence, Houstan (1987, in Nessipbayeva, 2012) stated that a teacher could be deemed successful in completing a competence-based teacher education only when he or she is capable of demonstrating his or her competence in three aspects, namely, knowledge, skills, and values. Meanwhile, Nessipbayeva (2012) herself mentioned that competence possesses these following traits: (1) a competency consists of one or more skills whose mastery would enable the attainment of the competency; (2) a competency is linked to all three of the domains under which performance can be assessed: knowledge, skills, and attitude; (3) possessing a performance dimension, competencies are observable and demonstrable; (4) since competencies are observable, they are also measurable. It is possible to assess a competency from a teacher's performance. (p. 149)

In terms of BIPA, generally a teacher should be competent in Indonesian language, language pedagogy, and teaching (Muliastuti, 2017). Specifically, Muliastuti (2016) laid out different kinds of competence that a BIPA teacher should obtain, referring to the Indonesian $\mathrm{Na}$ tional Qualification Framework (Kerangka Kualifikasi Nasional Indonesia or KKNI), regulated in the Decree of Indonesian Ministry of Education and Culture No. 73 Year 2013 (See Appendix a).

However, that framework presents an issue: up to now there is not any BIPA teacher education study program; only courses and concentration on BIPA teaching are currently available (Muliastuti, 2016). Muliastuti explained that BIPA teacher certification is nonexistent either, as it is stipulated in Constitution No. 20 Year 2003 Chapter 43 that a teacher certification program could only be administered by a higher education institution, which has an accredited teacher education program. Since up to now no higher institution has got a BIPA teacher education study program, consequently it is not possible to conduct a teacher certification.

However, at present there is still a framework that could be of use in order to prescribe the ideal competence of a BIPA teacher, which is the teacher competence in 2014 SPNG draft. Based on 
that framework, Muliastuti (2016) explained that in general a BIPA teacher produced by a BIPA teacher education program must possess four kinds of competence, namely: pedagogic competence, personality competence, professional competence, and social competence (Details of each competence are available in Appendix b).

It could then be agreed that teacher competence has got an essential role in improving BIPA teaching and its many aspects have been laid out in the above framework. One aspect which becomes the focus of this study is the pedagogic competence, as this has the strongest influence toward the teaching learning process in class.

Pedagogy wise, a competent BIPA teacher naturally is not only proficient at theories, but also adept at materializing them skillfully, effectively, and efficiently into classroom instructions in order to ensure that the learning goals are achieved and to help the students to genuinely learn. As explained by Agustina, Andayani, \& Wardani (2013), the very success of a teaching learning process indeed relies on a couple of factors, which include among others, systematic planning, and the competence of its teachers.

Agustina et al. (2013) elaborated further that the planning must be carried out according to an existing standard and the teaching-learning process subsequently abides by the plan, while the teachers must have got the competencies required to implement that plan into the process, which include the capabilities to master and deliver the content materials, to conduct professional and well-designed evaluation, to pick the appropriate teaching materials and media, to utilize suitable teaching methods and strategies, and to manage the class, as well as how to deal with issues which might hamper students' learning process. Indeed, teacher's competence is undoubtedly a crucial part for the success of a teaching-learning process.

In terms of pedagogic competence, I would like to warn us about the danger of the "illusion of knowledge". Trapped inside an illusion of our competence, we might believe having grasped the latest development in the field of language teaching, while in fact, although capable of reciting the jargons smoothly, we are still stuck with teaching traditionally.

Plenty of researches have shown that traditional teaching practices-such as, grammar-based or teacher-based teaching-hamper student's progress. For example, in an almost century-long study, which has its results confirmed three times in 1984, 2007, and 2012. Cleary (2014) explained that it has been proven that traditional grammar teaching, which assigns the students to dissect and memorize sentence parts, does not help or even hampers the students to become proficient writers. Not to be misunderstood, Cleary never asserted that grammar focus is unimportant. Instead, he claimed that the traditional way of teaching it is ineffective. Such scientific evidences should encourage us, as language teachers, to depart from traditional teaching practices that are proven to be harmful for learners.

To my knowledge, there is not yet any literature for the notion of "illusion of knowledge". Truthfully, I borrowed this term from this following quote: "The 
greatest enemy of knowledge is not ignorance; it is the illusion of knowledge". While opinions differ, that quote is often associated with late Stephen Hawking, the worldrenowned physicist. Meanwhile, some other sources mentioned that that quote was originally uttered by Daniel J. Boorstin, a well-known writer, educator, and librarian (O'Toole, 2016).

Lav (2017) stated that quote could be interpreted as: "not knowing something is not a crime but claiming yourself of knowing everything despite knowing nothing leads you to darkness". Meanwhile, according to Ravi (2018), that quote says that not knowing something or having insufficient knowledge is not a problem to the learning or process of gaining knowledge, but instead, misconception about our own knowledge is what prohibits us from gaining knowledge or learning.

Therefore, in relation to teacher competence, I use the term "the illusion of knowledge" to illustrate a particular phenomenon: when we assume that we have mastered a theory in language pedagogy, while in reality, even though we could fluently recite the jargons and the definitions, we have not completely grasped the core concepts, nor genuinely integrated those into our classroom practices.

In this literature study, I intend to remind us all not to get ourselves trapped into such a situation because when we did, both our students and we ourselves would be disadvantaged. On one hand, if a teacher has not truly comprehended modern language pedagogy, let alone implemented that to classroom practice, he or she would only teach traditionally, and consequently, the students' learning would be impeded. On the other hand, it would be very unfortunate for a teacher to falsely measure his or her own competence. Under such mindset, most likely he or she would refuse to study further and thus, his or her professional development as a teacher would be hampered. Even worse, if his or her way of teaching were made as a role model or an example, his or her colleagues would be misled, keep on preserving traditional teaching practices, until who knows when.

Since this term is new, examples would be used to provide further illustration. A befitting example for the case of illusion of knowledge is the danger of 'digitalization'. With all potentials that it could offer, technology has indeed been applauded by many to be the primary key for improving the quality of teachinglearning process. For example, Susandi (2009) stated that Indonesian language teachers have to master and make use of ICT (Information and Communication Technology) in order to face globalization. Meanwhile, Kramsch \& Thorne (2002) argued that using ICT would convert foreign language teaching-from learning without context - to a more authentic one. Various studies, seminars, workshops, training, and policies have highlighted the importance of ICT mastery as one of the competencies that a teacher must possess these days. Hence, it is no wonder that many teachers are fervent to integrate ICT in their classrooms.

However, according to Lynch (2008), using technology only for the sake of showing off how modern our classroom is, is a waste of time, money, and resources. Lynch explained that the true purpose of using technology in a classroom is to 
change the way we teach and to renew the way students learn, not merely to digitalize traditional teaching practices that we have always been doing. Holland (2007) critiqued that there is no fundamental difference in digitalizing traditional teaching practices, as learners remain passive consumers of a process that still centers on the teacher, and they do not become active producers of knowledge.

Indeed, our teaching practice does not automatically become innovative nor transformative, simply because we now explain grammar rules in MS Power Point or Prezi, because our students now submit their homework through Google Docs or in a blog post, or because our students do their multiple item exams through cool apps on their smartphone. Teaching using technology should make students more active mentally as they think more critically, are required to perform evaluation, and are encouraged to produce things (Lynch, 2008), and should provide the students with bigger authority over their own learning process (Holland, 2017).

Thus, teaching traditionally in a digital package or so-called "digitalization" is an example for how teachers might get trapped inside the illusion of their competence in term of integrating ICT in language teaching. Getting trapped in such an illusion would obscure our evaluation about our true competence as an Indonesian language teacher.

\section{METHOD}

This paper is a theoretical study, in the sense that it uses different literatures as bases to form and support its argu- ments. This study is significant due to this following situation.

The teaching of Indonesian language for foreign speakers or more commonly referred to as BIPA (Bahasa Indonesia bagi Penutur Asing) is relatively new, and therefore this fact tends to result in two problems in term of its pedagogy.

Firstly, in an attempt to fill the gaps and holes in the pedagogy of teaching Indonesian language to foreign speakers by ourselves, we-the teachers - often find ourselves, our practices, and our reflection of this field disconnected with the bigger field of the teaching of foreign languages. Therefore, new paradigms that have been praised, approved, recommended, and implemented elsewhere sometimes have not been heard, thoroughly understood, and genuinely implemented in our country, Indonesia. They remain hearsays at best, and unknown at worst.

While many articles written on the subject of BIPA pedagogy acknowledge the importance of teacher's competence and highlight what teachers need to be pedagogically competent, discussion on these two issues are still often times shallow, cliché, impractical, out of date of newer trends, and disconnected from both larger and newer discussion in the field of foreign language teaching and learning.

For example, evaluating the BIPA practice in a university, while Agustina et al. (2013) managed to successfully break down what elements needed to ensure a success of a teaching-learning processsuch as lesson planning, evaluation, media, and teaching instructions - it could be said that their investigation has not 
reached latest insights that shed light on what it takes to carry out each of those elements better or more effectively. Likewise, while Sujana (2012) managed to point out the challenges of BIPA program, which include the teachers' inability to conduct proper evaluation or to teach effectively, his suggestions of promoting the use of rubrics or training the teachers to be more fun and creative were considerably lack of depth and antiquated. Meanwhile, another study carried out by Sari, Sutama, and Utama (2016) of BIPA program in a school in Bali has not gone further than discussing technicalities - such as time punctuality or lesson plan's structure neatness - and revealing basic teaching requirements - such as the need for diverse teaching methods and the importance of evaluation. While these elements are all indispensable, such a discussion could be considered of long ago. Indeed, in many articles discussing BIPA pedagogy, there are still rare to no mention at all of newer, current paradigms in foreign language teaching and learning, such as backward design, performance assessment, modes of communication, etc.

Secondly, without thorough grasps of these modern paradigms, we-BIPA teachers - try to create a unifying pedagogy in the name of "standardization", resulting in shallow, limiting interpretation of this powerful jargon. The colorful designs of BIPA programs everywhere does confuse students and prevent them from studying globally in smooth manner. For instance, Gajewski (2018) mentioned that the main problem of BIPA program in Indonesia is its confusing structure as one institution's BIPA pro- gram is different in curriculum from other institutions', and thus he argued that a centralization might help to resolve this issue. However, this is only one way to approach this matter.

Such suggestion, which is precisely reflected in the current standardization movement in the field of BIPA, has only translated itself into the enforcement of one competence standards, one standardized testing, one set of teaching materials, and one teaching approach. It does not promote collaboration or cooperation among BIPA teachers everywhereit does not give them a space to share with one another, results of years of unique experiences teaching BIPA globally-all in the name of mere sameness.

This whole situation arguably leaves many teachers insights and practices stuck in the past, traditional teaching or halfhearted, modern teaching. More thorough researches are indeed required to support this claim, while studies in this area is still limited. However, those who were around in BIPA training programs, workshops, and conferences would be able to immediately confirm this, as many topics discussed centered around shallow standardization attempts or scattered teaching practices.

This theoretical study starts by underlining the importance of teacher competence in the globalization era, as well as giving a warning about the danger of the illusion of knowledge, an original notion that the writer has come up with in the light of the discussion about teacher competence. It then examines different competencies that an Indonesian language teacher should possess in available frameworks. Based on the results, this pa- 
per provides brief review of the latest language pedagogies for each area. This paper is also a reflection paper, in the sense that, by the end of each section, reflection questions are provided to guide readers in evaluating their current teaching practices.

\section{FINDINGS AND DISCUSSION}

From the literature review above, three things could be prescribed in relation to the pedagogic competence that must be possessed by a BIPA teacher. Firstly, a competent BIPA teacher should master theories in the field BIPA, both in general and in specific. Secondly, in order to become an effective BIPA teacher, several aspects of pedagogic competence should be mastered, which are:

- able to develop and to carry out a BIPA curriculum;

- able to develop and to carry out BIPA evaluation process;

- able to develop and to implement BIPA teaching materials;

- able to understand BIPA teaching approaches and implement them to BIPA teaching methods;

- able to integrate ICT in BIPA teaching;

- able to create friendly learning space for all learners, and encourage the learners to be creative and cooperative; and

- able to take into consideration the learners' characteristics.

Then, thirdly, a competent BIPA teacher is not only fluent at memorizing theories about above aspects, but also capable of implementing all of them fully and effectively in their classroom practices.

Guided by those aspects of pedagogic competence above, this paper would lay out several trends in modern language pedagogy that are worth revisiting and reflecting.

\section{Curriculum Development}

In regard to BIPA curriculum development, it is crucial to pay attention to two aspects, namely 1) adherence to competence standards, and 2) logical curriculum development.

\section{Adherence to Competence Standards}

In my previous presentation at Konferensi International Pengajaran BIPA bagi Penutur Asing $X$ (the International Conference on the Teaching of Indonesian Language to Foreign Speakers X or KIPBIPA X) in 2017, titled the Death of Approach War and the Rise of Logical, Collaborative Teaching-Learning, I warned against the danger of misinterpreting standardization. Triggered by globalization, standardization has indeed become a mean to boost teaching quality (Sahlberg, 2004), but it should never be interpreted narrowly as "uniformity of everything" (Wijaya, 2017).

I would like to keep encouraging us to reconsider the enforcement of the Common European Framework of Reference for Languages (CEFR) — a standard commonly used among European countries - as the only standard for all BIPA teaching-learning. At a glance, such a unifying initiative seems like a progress. However, this one-sided decision has in actuality ignored or even undervalued teaching-learning system in other countries, and rejected the hard labors of 
teachers in other institutions/countries.

For an example, there are at least two standards used in the U.S., namely the standard developed by the American Council for the Teaching of Foreign Language (ACTFL) - a national standard for the teaching of foreign language which is commonly used in educational setting - and the one developed by the Interagency Language Roundtable (ILR) - a proficiency standard which is commonly used by federal government. It is impossible and even inappropriate to compel BIPA teachers in the U.S. to refer to CEFR, while they have worked hard to develop their BIPA program little by little based on the national standard in their country. Likewise, it would be implausible and improper to force BIPA teachers in China to refer to a standard used by European countries, as they naturally adhere to their own country's education system and standard.

It should not matter whether the standard used by BIPA teacher/program adhere to CEFR, ACTFL, ILR, or local standards. What matters is for standards to be comparable. Therefore, standardization should be interpreted as awareness of the importance of compatibility between learning spheres and efforts to create comparison means among different standards. All in all, the first notion that a BIPA teacher should fully comprehend and genuinely implement is adhering his or her curriculum development to any valid competence standard.

\section{Logical Curriculum Development}

In term of curriculum development, Shrum and Glisan (2010) suggested using a modern approach, Backward Design, which is firstly coined by Wiggins and McTighe. Shrum and Glisan explained that this model is the very opposite of the traditional approach which centers on textbook or teacher. Furthermore, this model will help teachers to avoid the "twin sins" of traditional design, which are 1) hands-on without being minds-on, and 2) coverage (Wiggins and McTighe, 2005).

According to them, the first sin occurs when a class merely focuses on activities - usually those which are fun for learners-but does not teach essential concepts and does not have/lacks of measurable learning evidences. In such a class, learners are busy with assorted activities, but are not provided with opportunities to reflect on their meaning nor to relate those to their learning objectives. As the result, their learning process does not proceed anywhere intellectually. In such situation, insight or achievement takes place accidentally, if ever happens at all.

Meanwhile, the second sin takes place when a teacher overly focuses on covering a textbook, because he or she treats that textbook as the curriculum itself. Consequently, learning is constrained and minimum in results. To avoid those two sins, it is highly necessary to follow the curriculum development framework recommended by Backward Design, as shown in Figure 1. 


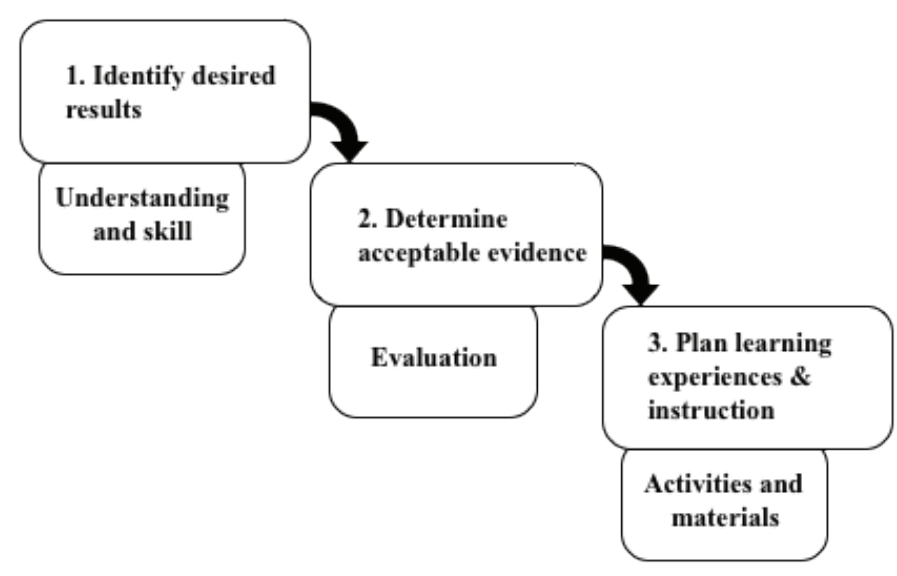

Figure 1. Steps of Backward Design (Source: Adapted from Wiggins \& McTighe (2005)

In short, when developing a curriculum, BIPA teachers must first depart from identifying desired results, which are based on valid competence standards and which include knowledge, comprehension, and competence. Afterward, they determine what evidences could be used to measure the results and what instruments could be utilized. Only then should the teachers develop relevant activities and teaching materials, which would help their students to fulfill the expected learning outputs, which means they have successfully completed their learning process.

Through such a planning, BIPA teachers are expected to successfully craft a logical, relevant, and intertwined learning process from the start to the end, and thus, learners would be able to learn effectively. Following this design, teachers would no longer make planning merely based on which activities and materials would make learners entertained. Of course, there are more aspects that we should pay attention to from Backward Design, but considering the limit of this paper and its nature as a review, it is not possible to cover them all here.

\section{Reflection Questions on Curriculum Development}

Below are several questions that we could use to reflect on our curriculum development practices: (1) Have we based our BIPA curriculum development on a valid competence standard? (2) Have we developed our curriculum-whether for the whole program, one level, a syllabus, or a meeting lesson plan-starting from identifying the desired outputs, which include knowledge, comprehension, and competence? (3) Do we develop evaluation-measurable learning evidences as well as assessment methods-before or after we decide the teaching activities and materials? (4) Have we developed our teaching activities and materials logically based on what would help our students to attain the learning evidences, or randomly based on what we consider would amuse or entertain our students?

\section{Assessment and Activities Development}

Nowadays, it has been agreed universally that the ultimate goal of foreign language learning is to enable the learners to communicate using the language that they are learning, or in short, to obtain communicative competence (Canale \& Swain, 1980).

The teaching of BIPA is no different, as Muliastuti explained that the study of Indonesian language for foreign learners aims to enable them to communicate well in both speaking and writing (2017). Therefore, it only makes sense that the assessment should examine, measure, or evaluate students' competence in using the target language that they are learning. 


\section{New Paradigm in Assessment}

In regard to assessment, it is crucial for us to truly comprehend the differences between the old and new paradigm, as presented in Appendix c. It could be seen that the new paradigm dictates smooth connection between assessment and activities. In actuality, this is in line with the approach depicted in Figure 2.

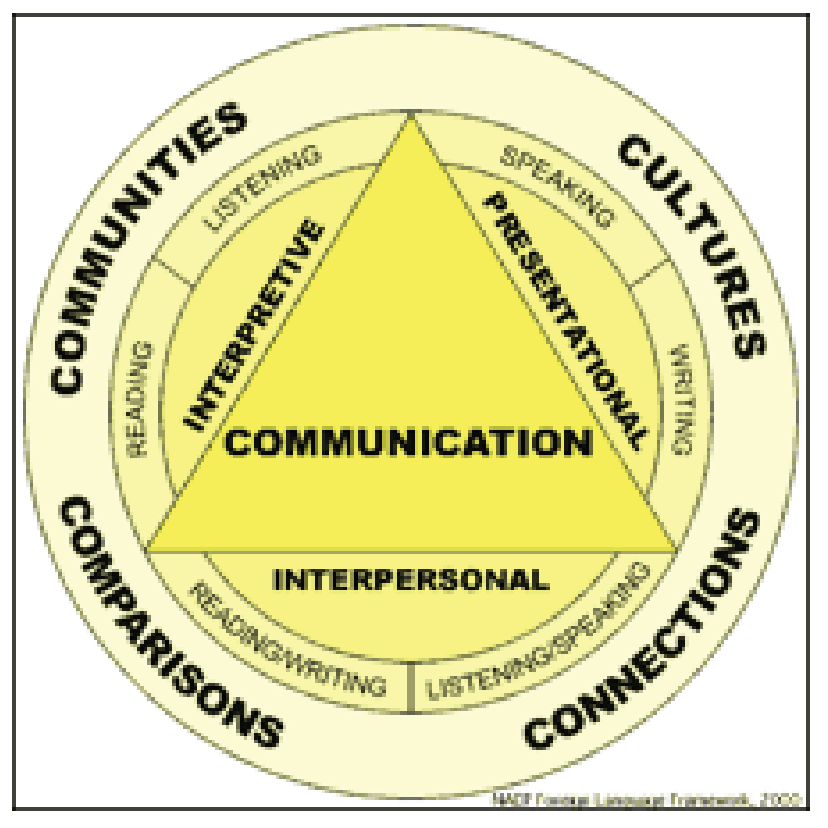

Figure 2. NAEP Framework for Proficiency Assessment (Source: CARLA (2015a)

This figure was developed by a committee of language teachers in the U.S. for the Foreign Language National Assessment of Educational Progress (FLNAEP) in order to illustrate the interconnection between foreign language learning and the Five C's of the National Standards for Foreign Language Learning (will be further explained in another section below)

It can be seen in Figure 2 that the center of learning-which would determine both assessment and activities-remains communication. Yet, both assessment and activities pay attention to three modes of communication, namely interpretive mode, interpersonal mode, and presentational mode (further explained below). This figure emphasizes that communicative competence assessment is incomplete when missing those three modes. Therefore, it is clear that communicative competence should not be interpreted as "yang penting pemelajar bisa ngobrol" (the most important aspect of teaching communicatively is the students being able to talk). There are deeper aspects that should be considered.

Nevertheless, the most important concept conveyed in Figure 2 is that modern foreign language class no longer treats reading, writing, speaking, and listening as separate skills (CARLA, 2015a). The interconnection between those four skills in communication is what would enhance learning process, and therefore, assessment process should also reflect that interconnection.

To make it happen, it is necessary to blur the boundary between assessment and teaching-learning activities. In fact, CARLA recommends erasing that boundary completely as the ultimate goal that we all need to aim. According to CARLA, teachers should no longer pause teaching-learning process in order to carry out assessment, but instead, they should integrate the assessment right into teaching-learning experience itself.

Consequently, students would demonstrate what they have known, comprehended, and been capable of doing, while they are completing tasks. These tasks are not merely repetition of information, but implementation of what they 
have learned through authentic communicative situation. In short, learners learn communicatively, while receiving continuous feedback. This is the ambitious goal that we need to constantly thrive for in the area of assessment and activity development.

All in all, all of these pose two implications. Firstly, assessment no longer becomes a process which takes place by the end of teaching-learning process nor functions as the only determinant of grade/passing. In the contrary, assessment takes place throughout the whole teaching-learning process and functions to improve learners' competence. Secondly, while planning assessment, teachers also need to think of teaching-learning activities.

\section{Integrative Performance Assessment}

One method to realize the new paradigm into classroom practice is the Integrative Performance Assessment (IPA) (Shrum \& Glisan, 2010; CARLA; 2015c).

Shrum and Glisan (2010) explained that IPA is based on these following principles:

1. Performance is effectively assessed within tasks that test learners' knowledge and skills in real-world situations, i.e., in "authentic" contexts in which students use the language in their lives both within and outside of the classroom.

2. Performance-based tasks require students to "do something with the language" (complete a task) and not merely recite from memory.

3. Performance-based situations provide opportunities for students to use a repertoire of skills, areas of knowledge, and modes of communication in order to negotiate tasks; therefore, the IPA features an integrated sequence of tasks reflecting the interpretive, interpersonal, and presentational modes of communication within a specific area of content.

4. In order for students to be successful in performance assessment, they need to be aware of what their performance should look like; students should be given models of the standards we expect them to achieve.

5. Performance-based assessment blends classroom instruction and experiences; it features a cyclical approach in which learners receive modeling, engage in practice, perform the assessment task, receive feedback from the teacher, engage in additional practice, perform another task, etc.

6. Assessment can improve performance if students receive feedback in their attempts to complete tasks.

7. Teacher feedback of high quality is that which provides learners with information regarding their performance as compared to model performance. Based on clearly defined criteria, teacher comments address whether the student performance "meets" the expectations for the level, "exceeds" the expectations, or "is not there yet." Comments do not consist of judgmental statements such as, "That was good" (Glisan et al., 2003, p. 9-10).

8. Performance-based assessment requires more time than traditional testing, but the time is justified since this type of assessment is linked closely to instruction and leads to improvement in student performance. (p. 419) 
In short and in general, the steps to develop an IPA unit follow the pattern in Figure 3 below. It can be seen that the first three stages of IPA development are in line with the concept of Backward Design. The process begins by referring to a standard in order to determine the learning theme and objectives.

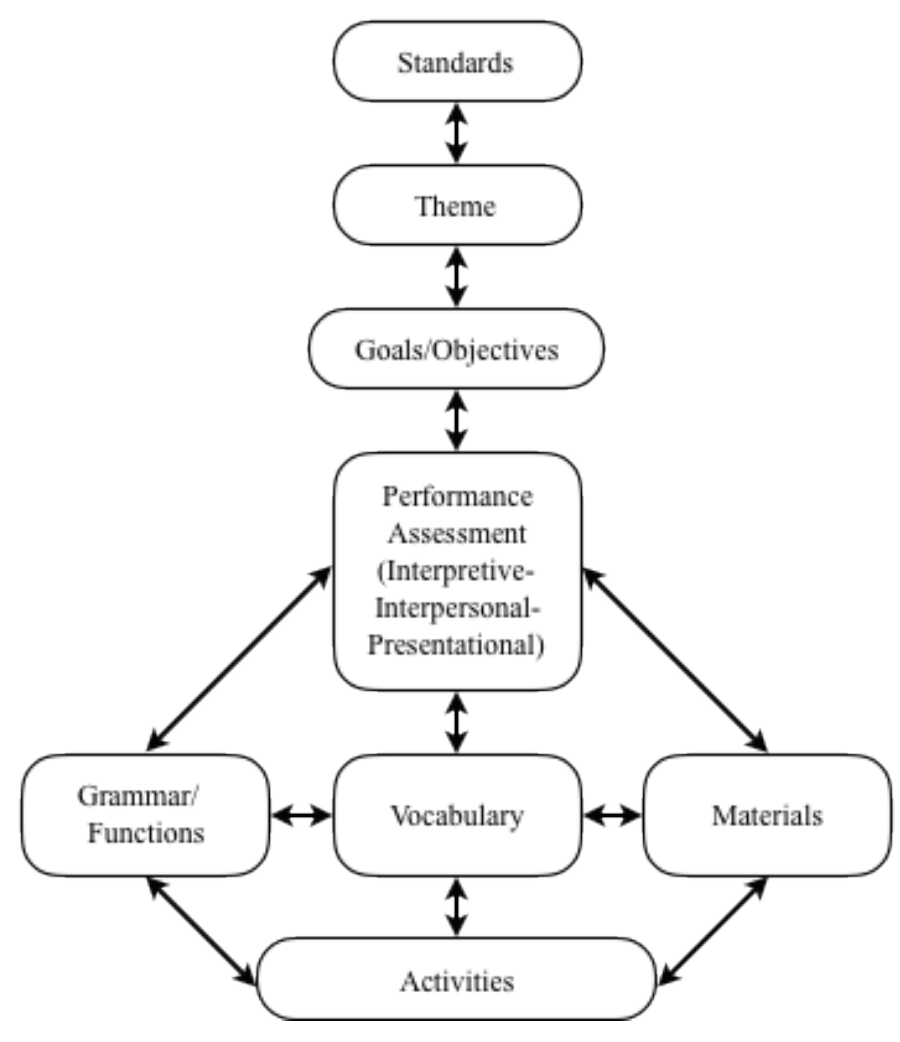

Figure 3. Steps to Develop IPA (Source: Adapted from CARLA (2015c)

Afterward, teachers determine performance assessment in three modes of communication, namely interpretive mode, interpersonal mode, and presentational mode (will be elaborated further below). Then, teachers determine various language aspects that are required to enable assessment and/or teaching-learning activities, including grammar or language functions, vocabularies, and materials. Finally, teachers develop more specific lesson plan for the class, which include learning activities.

Since this paper is merely a review, it will not elaborate IPA further. In case you are interested to study IPA further, please check references of this paper.

All in all, it could be seen that such an approach does not dictate the only possible method or assessment instrument. The important point to note is that our development follows logical and integrated flow.

\section{Steps of Teaching-Learning Activities}

The sequence of traditional teachinglearning activities normally follows two kinds of pattern. In the first pattern, teaching-learning activities in a language classroom are divided into four language skills, which are reading, listening, speaking, and writing. Grammar focus and vocabulary are inserted in the middle somewhere.

In the second pattern, which is slightly less traditional, teaching-learning activities in a foreign language classroom are still divided into those four skills, but they are divided further so as to be more organized and logical. The second pattern goes like this: A class starts with a presentation of a model, followed by a dissection of that model-in terms of language and discourse-, followed by an exercise to imitate the model in groups or in pairs, and ended with a more independent, individual exercise.

Nevertheless, in both patternswhether less or more organized-the approach utilized is still traditional, as lan- 
guage skills are still viewed as unrelated phenomena existing in a vacuum, separated one from another.

In a more modern approach, as conveyed by Shrum \& Glisan (2010) and CARLA (2015a), language is no longer viewed as an end, but instead, as a mean to communicate, while each language skill is placed as a tool to enable different kinds of communication.

This view will present us with the three modes of communication, namely interpretive mode, interpersonal mode, and presentational mode. The interpretive mode focuses on the use of language through reading or through listening to receive, to attain, or to absorb information. Meanwhile, the interpersonal mode focuses on the use of language through reading-writing and through listeningspeaking in order to exchange information. Finally, the presentational mode focuses on using the language through writing and speaking to deliver information. In this model, four language skills still exist, but as parts of for communication. They are tools that enable communication, and not the communication goals in themselves.

Paying attention to these three modes of communication while making lesson plan (and assessment too, of course) will bring about several implications. Firstly, teaching-learning activities that we present in our classroom will become more communicative and authentic, because learners will really do something with the language as they communicate in a real context. Thus, learners no longer stare at reading text in order to answer reading comprehension questions, or in order to create similar text. Learners now study things to prepare them for next, real communication.

Secondly, the kinds of activities that we could present in our classroom would be limitless, but they still follow logical flow. Guided by this approach, learners would still receive a model in the beginning. However, from that model, they do not only analyze the form of the text nor the language aspects, but they genuinely learn substantial information that they would use in the next phase of their learning. In the second phase, triggered by language model and information that they have received, learners have discussion with their teacher and peers. Finally, from the results of their study both in and outside their classroom, they will present new information creatively during the third phase.

It could be seen that following this model, the sequence is organized, but the kind of model and activities that we can present is various. Learners would not be stuck with, "Ah, today I learn reading!" or "Ah, today I learn listening".

So, using the more modern approach as a guidance, teachers now give meaning or context to every step in a learning unit/activity based on the kind of interaction or communication that takes place. Such a design does require more preparation time, but it truly reflects activities that we do in our daily life, besides showing a more logical, organized, and purposeful teaching-learning flow.

\section{Questions Around Assessment and Ac- tivities Development}

Below are several questions that we could use to reflect our performance so far in term of developing assessment and 
activities: (1) Do we still develop learning assessment traditionally according to the old paradigm, or have we moved forward to modern assessment based on the new paradigm? (2) Have we integrated our assessment with teaching-learning activities and provide meaningful feedback for learners, or do we still make assessment a mere requirement to pass a class/a program? (3) When developing assessment and teaching-learning activities, have we referred to communicative competence, which provides opportunities for learners to use target language? (4) Do we still separate assessment and teaching-learning activities based on four language skills, or have we developed both after considering different kinds of communication that take place in real life?

\section{Teaching Material Development}

In term of developing teaching material, this paper will discuss two things, namely 1) coverage of teaching material, and 2) integration of ICT.

\section{Coverage of Teaching Material}

Determining teaching material actually is closely related to teaching approach that we use. Muliastuti (2017) suggested using an integrated approach which naturally is a teaching-learning approach that enables learners, individually and in groups, to search for, to dig, and to discover concept and principle holistically and authentically through the umbrella of a theme. Besides, Muliastuti explains that Indonesian language material that we develop should also present cultural substance. Finally, Muliastuti explains that integrated learning is holistic, meaningful, authentic, and active. However, she admits one drawback of the integrated approach, which is the difficulty in picking a theme. According to Muliastuti, teachers tend to provide a shallow them for learners and thus it becomes less useful for the learners, and teachers often overly focus on activities, consequently making materials or concepts neglected.

To ensure that the learning theme remains meaningful and that the materials that follow, will trigger learners' critical thinking, Wiggins \& McTighe (2005) recommends using Essential Question as a guide. With such a question as a guide for the learning theme, teaching-learning activities would encourage learners to participate in a sort of research; they are provided with a research question that they will try to answer from their learning activities. Their learning materials are also expected to help them discover that answer. Therefore, from their activities and materials, learners would genuinely learn substantial things, and not only, for examples, family members of artificial madeup character named Budi or vacation experience of an imaginary figure named Ani.

Of course, not all questions could be used as Essential Question. Wiggins \& Mctighe lay out that Essential Questions are not usually answerable by one short sentence since such questions naturally trigger thought, stimulate curiosity, and invite more questions. Besides that, Essential Questions also encourage learners to search for information from other fields.

"What is the religion of majority of Indonesians?" is just a regular question which does not require too much thinking. However, "What does religion mean 
for Indonesians?" is the kind of question which requires further thinking and is related to various aspects/other subjects.

In this global era, foreign language learners no longer learn a language merely for the sake of learning the language itself. A critical learner surely expects to learn a foreign language while also learning a pertinent aspect from the life of the speakers of that language. Considering the limitation of this paper, this approach will not be elaborated in details either.

All teachers commonly agree with integrating cultural content in Indonesian language teaching and learning. However, more often than not, we integrate that randomly. Often times, we define culture as merely traditional art, such as songs, dances, or clothes. To help organize our integration of cultural content, we could use the concept prescribed in the Five C's of the National Standards for Foreign Language Learning (CARLA, 2015d).

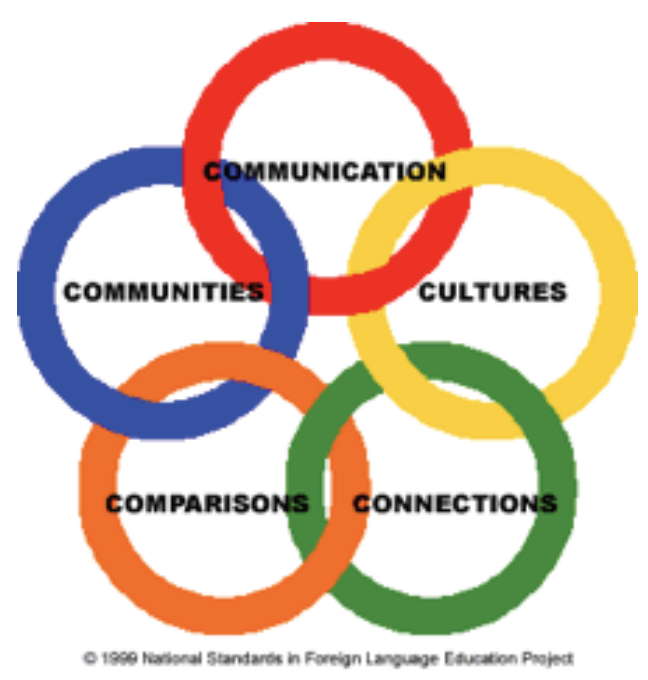

Figure 4. Five C's from National Standard (Source: CARLA (2015d)

As can be seen in Figure 5 above, the Five C's are communications, cultures, connections, comparisons, and communities. The first part, communications, as well as its three modes have been explained above, while the other four will be elaborated as follow.

Cultures in factuality cover all aspects that could help learners to fully comprehend native speakers of the language which they are learning. This part includes three subparts, which are Products, Practices, and Perspectives.

In Products, teachers teach about things produced by a culture, including clothing, songs, dances, paintings, traditional houses, and monuments. Then, in Practices, teachers teach from trivial matters, such as the custom to use right hand to give something, to customs during religious day celebration. Finally, in Perspectives, teachers teach different points of view which become basis for the whole culture, such as the role of religion in Indonesian people's life.

However, the learning of culture does not stop at getting to know it. The third $\mathrm{C}$, which is connections, and the fourth one, which is comparisons, underline the need for learners to make further analysis. After they learn an aspect of culture, learners are expected to connect it with other subjects. For example, as learners learn about Eid, they also learn the mudik (going back to area of origin) tradition (transportation) and the rising price of goods during the holiday (economy) which both come with the celebration day. Besides that, learners are also asked to compare the target language with their own culture. For example, when they learn about greeting, learners compare how hierarchy plays a role in social life. All of these would make the teaching of foreign language full of contents. 


\section{Integration of ICT}

Not many would be conveyed in this paper in regard to the integration of ICT. As has been explained earlier in this paper, ICT does have huge potentials to transform foreign language teaching and learning-from a traditional one to a modern one, which is authentic and communicative and which empowers learners to become intellectually active and critical.

However, it is crucial to remember that ICT should never be used merely for the sake of using ICT. Nor should it be used solely for the sake of making classes fun for students. The integration of ICT should follow the framework of Backward Design, which is helping teachinglearning activities or assessment in order to attain the learning objectives effectively.

\section{Questions Around Teaching Material Development}

There are several questions that we could reflect on in relation to teaching material development, as follow: (1) Have we chosen a learning theme which encourages our learners to learn genuinely substantial concept and knowledge? (2) Have we developed teaching material which encourages our learners to learn critically and to be active intellectually? (3) Have we developed teaching material which presents cultural content thoroughly in an organized manner? (4) Have we chosen ICT in a manner which supports learners' attainment of learning objectives?

\section{CONCLUSION}

The competence of Indonesian language teachers is one of the keys to improving the quality of Indonesian language teaching and learning. When being trapped inside the illusion of knowledge, Indonesian language teachers might wrongly estimate their own true competence, thus only capable of fluently reciting different language pedagogy jargons, but in fact, are not capable of truly grasping the core meaning, let alone implementing it into teaching practice.

Being trapped in such an illusion, Indonesian language teachers would not leave traditional teaching, which truthfully harms both the teachers themselves and the learners. This paper lays out briefly several concepts in modern foreign language teaching and learning which supposedly guide our teaching practice for our reflection.

In relation to pedagogic competence and in line with the warning that this paper provides, it is crucial to remember that the concepts explained in this paper is not for being memorized as jargons either. Instead, they are meant to be truly studied to grasp the essences and to be fully implemented into classroom instructions.

Then, it is not my intention to impose the concepts offered in this paper as the only correct approach, which everyone should adopt. Moreover, I realize that same concept or thought might appear in different packages. Whichever label used should not matter, as long as we are guided rightfully in developing modern teaching practice which is more effective for the learners' learning process. 
All in all, all questions that we should reflect on together from this literature review are as follow.

- Have we based our BIPA curriculum development on a valid competence standard?

- Have we developed our curriculumwhether for the whole program, one level, a syllabus, or a meeting lesson plan-starting from identifying the desired outputs, which include knowledge, comprehension, and competence?

- Do we develop evaluation-measurable learning evidences as well as assessment methods-before or after we decide the teaching activities and materials?

- Have we developed our teaching activities and materials logically based on what would help our students to attain the learning evidences, or randomly based on what we consider would amuse or entertain our students?

- Do we still develop learning assessment traditionally according to the old paradigm, or have we moved forward to modern assessment based on the new paradigm?

- Have we integrated our assessment with teaching-learning activities and provide meaningful feedback for learners, or do we still make assessment a mere requirement to pass a class/a program?

- When developing assessment and teaching-learning activities, have we referred to communicative competence, which provides opportunities for learners to use target language?

- Do we still separate assessment and teaching-learning activities based on four language skills, or have we developed both after considering different kinds of communication that take place in real life?

- Have we chosen a learning theme which encourages our learners to learn genuinely substantial concept and knowledge?

- Have we developed teaching material which encourages our learners to learn critically and to be active intellectually?

- Have we developed teaching material which presents cultural content thoroughly in an organized manner?

- Have we chosen ICT in a manner which supports learners' attainment of learning objectives?

- Have we freed ourselves from jargons which obscure our understanding of our true competence, which confine our teaching practice, and which constrain our professional development as an Indonesian language teacher?

In the end, I hope that this literature review helps us all as Indonesian language teacher to reflect on our teaching practice, as well as making contribution to our collective effort to improve the competence of Indonesian language teachers for the development of the field of the teaching of Indonesian language and Indonesian language itself.

\section{REFERENCE}

Agustina, R., Andayani, \& Wardani, N.E. (2013). Implementasi pembelajaran bahasa Indonesia bagi penutur asing di UPT P2B Universitas Sebelas Maret Surakarta. Jurnal Pendidi- 
kan Bahasa dan Sastra, 1(2): 140-154. Retrieved from https://core.ac.uk/ download/pdf/12347443.pdf .

Altun, T. (2011). INSET (In-Service Education and Training) and professional development of teachers: A comparison of British and Turkish cases. US-China Education Review A, 6, 846858. Retrieved from https://files.eric.ed.gov/fulltext/ED529375.pdf .

Canale, M., \& Swain, M. (1980). Theoretical bases of communicative approaches to second language teaching and testing. Applied Linguistics, 1(1): 1-47. Retrieved from https:// doi.org/10.1093/applin/I.1.1 .

CARLA. (2015a). A NAEP framework for performance assessment. In What am I assessing?. Retrieved from http://www.carla.umn.edu/assessment/vac/WhatAssessing/p_2.ht$\mathrm{ml}$.

CARLA. (2015b). Create a standardsbased Integrated Performance Assessment unit step-by-step. Retrieved from http://www.carla.umn.edu/ assessment/vac/CreateUnit/p_1.ht$\mathrm{ml}$.

CARLA. (2015c). Relationship of instruction and assessment. In Why assess?. Retrieved from http://www. carla.umn.edu/assessment/vac/ WhyAssess/p_4.html.

CARLA. (2015d). The five Cs of the world-readiness standards. In Modes of communication: Models informing assessment. Retrieved from http:// www.carla.umn.edu/assessment/ vac/Modes/p_1.html.

Cleary, M. N. (2014, February 25). The wrong way to teach grammar. The Atlantic. Retrieved from http:// www.theatlantic.com/education/archive/2014/02/the-wrong-way-toteach-grammar/284014/.

Gajewski, D. M. (2018). Evaluasi program pengajaran BIPA-Suatu perspektif pelajar asing [Proceeding]. Presented in Seminar Nasional SAGA \#1. Retrieved from http://seminar.uad.ac. $\mathrm{id} / \mathrm{index} \cdot \mathrm{php} / \mathrm{saga/article/}$ view/109.

Holland, B. (2017, February 22). Are we innovating, or just digitizing traditional teaching? Edutopia. Retrieved from https://www.edutopia.org/article/are-we-innovating-or-just-digitizing-traditional-teaching-beth-holland

Kramsch, C., \& Thorne, S. L. (2002). Globalization and the teaching of 'communication skills'. In D. Block \& D. Cameron (Eds.), Globalization and language teaching (pp. 67-82). London: Routledge.

Lav, K. (2017, August 31). What did Hawking mean by "the greatest enemy of knowledge is not ignorance, it is illusion of knowledge"? Quora. Retrieved from https://www.quora. com/What-did-Hawking-mean-bythe-greatest-enemy-of-knowledge-isnot-ignorance-it-is-illusion-ofknowledge/answer/Kumar-Lav-5.

Lynch, M. (2008, September 6). Digitizing traditional teaching isn't innovative. Education Week. Retrieved from http://blogs.edweek.org/edweek/ education_futures/2017/09/why_ digitizing_traditional_teaching_ isnt_innovation.html.

Muliastuti, L. (2016). Kompetensi pengajar BIPA dalam mendukung internasionalisasi bahasa Indonesia [PPT]. Presen- 
tation delivered at Pembekalan Pengajar BIPA ke Luar Negeri on January 23, 2016.

Muliastuti, L. (2017). Bahasa Indonesia bagi Penutur Asing: Acuan Teori dan Pendekatan Pengajaran. Yayasan Pustaka Obor Indonesia: Jakarta

Nessipbayeva, O. (2012). The competencies of modern teacher [Paper]. Presentation delivered at the 10th Annual Meeting of the Bulgarian Comparative Education Society, June 12-15. Bulgaria: Kyustendil. Retrieved from https://files.eric.ed.gov/fulltext/ED567059.pdf .

Sahlberg, P. (2004). Teaching and globalization. International Research Journal of Managing Global Transitions, 2(1), 65-83. Retrieved from http://pasisahlberg.com/wp-content/uploads/2013/01/Teaching-and-globalization.pdf.

Shrum, J. L., \& Glisan, E. W. (2010). Teachers Handbook: Contextualized Language Instruction (4th ed.). Boston, MA: Heinle Cengage Learning.

O'Toole, G. (2016, July 20). The greatest obstacle to discovery is not ignorance-It is the illusion of knowledge. Quote Investigator. Retrieved from https://quoteinvestigator. com/2016/07/20/knowledge/.

Ravi. (2018, March 20). What did Hawking mean by "the greatest enemy of knowledge is not ignorance, it is illusion of knowledge"? Quora. Retrieved from https://www.quora.
com/What-did-Hawking-mean-bythe-greatest-enemy-of-knowledge-isnot-ignorance-it-is-illusion-ofknowledge/answer/Ravi-1098.

Sari, N. P. A. P., Sutama, I. M., \& Utama, I. D. G. B. (2016). Pembelajaran Bahasa Indonesia bagi Penutur Asing (BIPA) di Sekolah Cinta Bahasa, Ubud, Bali. Jurnal Pendidikan Bahasa dan Sastra Indonesia Undiksha, 5(3). Retrieved from https://ejournal.undiksha.ac.id/index.php/JJPBS/article/viewFile/8635/5628.

Sujana, I. M., (2012). Program Bahasa Indonesia untuk Penutur Asing (BIPA: Peluang, tantangan, dan solusi [Presentation paper]. Presentation delivered at Seminar Internasional Menimang Bahasa Membangun Bahasa on September 5-6, 2012. Retrieved from https://www.researchgate.net/publication/315643256_PROGRAM_ PEMBELAJARAN_BAHASA_INDONESIA_UNTUK_PENUTUR_ ASING_BIPA_PELUANG_TANTANGAN_DAN_SOLUSI.

Susandi. (2009). Problematika yang dihadapi guru Bahasa Indonesia dalam era globalisasi dengan perkembangan iptek terutama dalam bidang ICT [Blog]. Retrieved from https:// $\mathrm{s}$ u s a n d i. w o r d p r e s s. com/2009/11/21/problematikapendidikan-bahasa-indonesia/.

Wiggins, G. P., \& McTighe, J. (2005). Understanding by Design (2nd ed.). Alexandria, VA: ASCD. 
Appendix a.

Competences of BIPA teachers according to KKNI

According to this framework, a BIPA teacher should at least attain the $6^{\text {th }}$ level which equals to an undergraduate level of education (S1 or D4). Therefore, a BIPA study program is supposed to produce graduates with these following competences:

- able to make use of ICT in BIPA and able to adapt to any situation faced in order to solve an issue;

- able to master theoretical concepts in BIPA in depth, both in general and in specific, and able to formulate procedural solution to an issue;

- Able to make strategic decision in the field of BIPA based on information and data analysis, and to give recommendations in choosing different alternative solutions; and

- Able to be responsible for BIPA teaching and the attainment of BIPA institution.

Meanwhile, a graduate from BIPA Teacher Education Program (Program Pendidikan Guru BIPA or PPG BIPA), who is in the $7^{\text {th }}$ level (Teacher Profession) is expected to be:

- able to plan and to manage BIPA resources under his responsibility, and to evaluate comprehensively BIPA teaching by utilizing ICT, in order to make steps for BIPA teaching strategic development;
- able to solve science, technology, and or art issues in the field of BIPA through monodisciplinary approach; and

- able to carry out research in the field of BIPA and to make strategic decision with full accountability and responsibility for all aspects under his or her expertise care.

\section{Appendix $\mathbf{b}$. \\ Competences of BIPA teacher according to 2014 SPNG draft}

Each competence of a BIPA teacher according to SPNG draft could be detailed as follow:

\section{Pedagogic competence}

A graduate of BIPA teacher education program is expected to be able to:

- develop a learning environment in order to develop BIPA students' potentials in studying;

- develop BIPA curriculum development in the form of lesson plan;

- use approach, model, procedure, and teaching technique according to the characteristics of BIPA students;

- develop BIPA teaching materials which are in accordance with BIPA students' competence level;

- develop and implement lesson plan for BIPA teaching-learning process effectively and creatively;

- plan and carry out assessment of BIPA study and use it to improve students' study result; 
- improve the quality of BIPA teaching and learning process based on process assessment and study result assessment;

- implement ICT in lesson plan and in BIPA teaching and learning process;

- develop and maintain a safe learning environment, which challenges BIPA students to be creative;

- develop cooperative social relationship between BIPA students; and

- treat BIPA students in fair and friendly manner.

\section{Personality competence}

A graduate of BIPA teacher education program should reflect attitude which:

- is in accordance with Indonesian national religious, law, social and cultural norms;

- is honest, noble, and exemplary for students and society;

- is steady, stable, mature, wise, and charismatic;

- is innovative and creative in developing educational process;

- is patient while interacting with students;

- cares for students' learning success;

- shows high working ethics and responsibility;

- has learning habit; and

- strongly upholds teaching profession ethics code.

\section{Professional competence}

A graduate of BIPA teacher education program must master:

- pedagogical content which is the expertise of BIPA teaching profession;

- ways to continuously develop profession capabilities as a BIPA teacher;

- pedagogy in the field of Indonesian language;

- pedagogical content approach and organization; and

- ways to study physical, social, and cultural environment, and to use them as learning resources for BIPA students.

\section{Social competence}

- A graduate of BIPA teacher education program is expected to be able to:

- communicate with students in a language that they comprehend;

- communicate professionally and politely with parents and society;

- communicate with colleagues about different learning issues and teachinglearning development

- participate in various society activities;

- be inclusive, act objectively, and not be discriminative against gender, religious, racial, physical, family, and socioeconomic backgrounds; and

- adapt to working place in all areas in Indonesia which are socially, culturally, economically, and religiously diverse. 
Appendix c.

Old Paradigm vs. New Paradigm in Assessment

\begin{tabular}{|c|c|c|}
\hline & Old Paradigm & New Paradigm \\
\hline $\begin{array}{l}\text { Purpose of Assess- } \\
\text { ment }\end{array}$ & $\begin{array}{l}\text { To evaluate learners and assign } \\
\text { grades }\end{array}$ & $\begin{array}{l}\text { To assess learner progress in proficiency } \\
\text { and attainment of standards; to guide and } \\
\text { improve student performance; to evaluate } \\
\text { and inform instruction and program de- } \\
\text { sign; seamless connection between in- } \\
\text { struction and assessment }\end{array}$ \\
\hline $\begin{array}{l}\text { Place of Assessment } \\
\text { in Planning and In- } \\
\text { struction }\end{array}$ & $\begin{array}{l}\text { Assessment occurs at the end of } \\
\text { instruction }\end{array}$ & $\begin{array}{l}\text { Identification of assessment evidence be- } \\
\text { fore learning experiences are planned so } \\
\text { that targeted goals and performances } \\
\text { guide classroom practices (backward de- } \\
\text { sign) }\end{array}$ \\
\hline $\begin{array}{l}\text { Types of Assess- } \\
\text { ment }\end{array}$ & $\begin{array}{l}\text { Focus on either formative or } \\
\text { summative assessment; limited } \\
\text { number of assessments; largely } \\
\text { paper- and-pencil and textbook } \\
\text { tests }\end{array}$ & $\begin{array}{l}\text { Balance of formative and summative as- } \\
\text { sessments; multiple measures; focus on } \\
\text { performance in authentic tasks; integra- } \\
\text { tion of technology }\end{array}$ \\
\hline $\begin{array}{l}\text { Assessment Content } \\
\text { \& Formats }\end{array}$ & $\begin{array}{l}\text { Testing of grammatical knowl- } \\
\text { edge and vocabulary; contexts } \\
\text { devoid of meaning; discrete- } \\
\text { point items, often with one right } \\
\text { answer }\end{array}$ & $\begin{array}{l}\text { Integrated assessment of } 3 \text { modes of com- } \\
\text { munication and goal areas of standards; } \\
\text { meaningful contexts; open- ended for- } \\
\text { mats, allowing for divergent responses and } \\
\text { creativity; oral assessments, TPR, observa- } \\
\text { tion checklists }\end{array}$ \\
\hline Role of Learner & $\begin{array}{l}\text { Has limited opportunities to } \\
\text { demonstrate knowledge and } \\
\text { skills; must provide "right" an- } \\
\text { swers; receives little feedback } \\
\text { about how to improve perfor- } \\
\text { mance; has few opportunities to } \\
\text { learn as a result of assessment; } \\
\text { has no role in assessment plan- } \\
\text { ning or decision-making }\end{array}$ & $\begin{array}{l}\text { Has multiple opportunities to demonstrate } \\
\text { knowledge and skills; encouraged to be } \\
\text { creative in language use; receives rubrics } \\
\text { before assessment; receives regular feed- } \\
\text { back and coaching on how to improve } \\
\text { per- formance; learns as a result of assess- } \\
\text { ment; participates in assessment planning } \\
\text { and decision-making }\end{array}$ \\
\hline Role of Teacher & $\begin{array}{l}\text { Provides grades and corrective } \\
\text { feedback }\end{array}$ & $\begin{array}{l}\text { Describes targeted performance prior to } \\
\text { administering assessments; reports on stu- } \\
\text { dent progress; provides feedback and } \\
\text { coaching for improvement; uses assess- } \\
\text { ment results to improve program and } \\
\text { teaching }\end{array}$ \\
\hline $\begin{array}{l}\text { Grading System/ } \\
\text { Feedback }\end{array}$ & $\begin{array}{l}\text { Points/grades given for correct } \\
\text { responses; corrective feedback }\end{array}$ & $\begin{array}{l}\text { Rubrics to describe range of performance } \\
\text { possible1; points/grades given for both ac- } \\
\text { curacy and creativity in language use; rich } \\
\text { feedback that describes how performance } \\
\text { could improve }\end{array}$ \\
\hline
\end{tabular}

Source: Shrum \& Glisan (2010, p. 396)

250 LITERA, Volume 18, Nomor 2, Juli 2019 